\title{
A landiolol alkalmazási lehetőségei a kardiológiai és intenzív terápiás ellátásban
}

\author{
Radics Péter dr. ${ }^{1 *}$ - Kiss Boldizsár dr. ${ }^{2 *}$ - Kovács Enikő dr. ${ }^{3}$ \\ Pilecky Dávid dr. ${ }^{4}$ - Ruzsa Zoltán dr. ${ }^{2,5}$. Straub Éva dr. ${ }^{2}$ \\ Fejér Csaba dr. ${ }^{2}$ - Gellér László dr. ${ }^{2}$. Merkely Béla dr. ${ }^{2}$ - Zima Endre dr. ${ }^{2}$ \\ ${ }^{1}$ Budai Irgalmasrendi Kórház, Kardiológia, Budapest \\ ${ }^{2}$ Semmelweis Egyetem, Általános Orvostudományi Kar, Városmajori Szív- és Érgyógyászati Klinika, Budapest \\ ${ }^{3}$ Semmelweis Egyetem, Általános Orvostudományi Kar, Aneszteziológiai és Intenzív Terápiás Klinika, Budapest \\ ${ }^{4}$ Klinikum Passau, Passau, Németország \\ ${ }^{5}$ Szegedi Tudományegyetem, Általános Orvostudományi Kar, II. Belgyógyászati Klinika és Kardiológiai Központ, \\ Invazív Kardiológiai Részleg, Szeged
}

\begin{abstract}
A landiolol intravénásan alkalmazandó, kifejezetten cardioselectiv, gyors hatású és rövid felezési idejü béta-1-receptor-blokkoló, mely elsősorban negatív chronotrop és inotrop hatással bír, vérnyomáscsökkentő hatása elhanyagolható. Fôleg hemodinamikailag instabil állapotú, supraventricularis ritmuszavarban szenvedő betegek kamrafrekvenciájának csökkentésére használható. Nagy esetszámú, randomizált vizsgálatok igazolták hatékonyságát szívmútétek után jelentkező pitvarfibrilláció megelőzésében, valamint súlyos akut szívelégtelenségben és szívmútétek posztoperatív szakában jelentkező pitvari tachyarrhythmiák kezelésében. Ezek mellett kisebb vizsgálatok alapján a használata biztonságosnak tünik akut myocardialis infarctusban, hatékony szeptikus állapotú, pitvarfibrillációban szenvedő betegek kamrafrekvencia- és ritmuskontrolljára, valamint nem cardialis mútétek esetén a pitvarfibrilláció prevenciójára és kezelésére. Sikerrel alkalmazható elektromos vihar esetén is, és jól használható angiográfiás coronaria-CT-vizsgálat előtt az optimális szívfrekvencia elérésére. A gyógyszer 2016 óta Európában, 2018 óta Magyarországon is elérhető.

Orv Hetil. 2022; 163(2): 53-62.
\end{abstract}

Kulcsszavak: pitvarfibrilláció, tachycardia, revascularisatio, szívelégtelenség, béta-blokkoló

\section{The application of landiolol in the cardiovascular and intensive care}

Landiolol is an intravenous, selective beta-1-receptor blocking agent with rapid onset of action and ultra-short halflife that has a predominant negative chronotropic and only mild negative inotropic effect without significant reduction of blood pressure. Landiolol is indicated to control the ventricular heart rate predominantly in patients with hemodynamic instability due to supraventricular tachyarrhythmia. Large randomized controlled trials have proven the efficacy of landiolol in the prevention of atrial fibrillation and atrial tachyarrhythmias in severe acute heart failure or post-cardiac surgery. Based on lower case-number studies, the administration of landiolol has been proven to be efficient and safe in rhythm and rate control in atrial fibrillation complicating acute myocardial infarction, sepsis, and in the prevention of atrial fibrillation in non-cardiac surgery. Landiolol may be used in electrical storm, and even during coronary CT-angiography to achieve an optimal heart rate for imaging. The drug is available in Europe since 2016 and in Hungary since 2018.

Keywords: atrial fibrillation, tachycardia, revascularisation, heart failure, beta-blocker

Radics P, Kiss B, Kovács E, Pilecky D, Ruzsa Z, Straub É, Fejér Cs, Gellér L, Merkely B, Zima E. [The application of landiolol in the cardiovascular and intensive care]. Orv Hetil. 2022; 163(2): 53-62.

(Beérkezett: 2021. július 3.; elfogadva: 2021. szeptember 10.)

*Radics Péter dr. és Kiss Boldizsár dr. megosztott első szerzők, a közlemény elkészítésében egyenlő mértékben vettek részt. 


\section{Rövidítések}

$\mathrm{ACE}=$ (angiotensin-converting enzyme) angiotenzinkonvertáló enzim; $\mathrm{ARB}=$ (angiotensin II receptor blocker $)$ angiotenzin-II-receptor-blokkoló; BNP = B-típusú natriureticus peptid; $\mathrm{CABG}=($ coronary artery bypass graft $)$ coronariaartéria-bypassgraft; $\mathrm{CI}=$ (confidence interval) konfidenciaintervallum; $\mathrm{CK}-\mathrm{MB}=($ creatine kinase myocardial band) szívizom-specifikus kreatin-kináz ; $\mathrm{CT}=$ (computed tomography) komputertomográfia; $\mathrm{HFpEF}=$ (heart failure with preserved ejection fraction) megtartott ejekciós frakciójú szívelégtelenség; HFrEF $=($ heart failure with reduced ejection fraction $)$ csökkent ejekciós frakciójú szívelégtelenség; LVEF = (left ventricular ejection fraction) bal kamrai ejekciós frakció; NSTE-ACS $=$ (nonST-segment elevation acute coronary syndrome) nem ST-elevációs akut coronaria szindróma; NYHA $=(\mathrm{New}$ York Heart Association) New York-i Kardiológus Társaság; OAT = (organic anion transporter) szervesanion-transzporter; OCT $=$ (organic cation transporter) szerveskation-transzporter; $\mathrm{OR}=$ (odds ratio) esélyhányados; PCWP = (pulmonary capillary wedge pressure) pulmonalis kapilláris éknyomás; STEMI = (ST-elevation myocardial infarction) ST-elevációs myocardialis infarctus; SVI = (stroke volume index $)$ verőtérfogat-index

A landiolol intravénásan alkalmazandó, kifejezetten béta-1-receptor-selectiv, ultrarövid hatású béta-blokkoló, mely elsősorban supraventricularis szívritmuszavarok frekvenciakontrolljára használható. A gyógyszert Japánban fejlesztették ki, és 2002 óta alkalmazzák a betegellátásban [1]. Európában 2016-ban, Magyarországon 2018-ban kapott engedélyt és vált elérhetővé a betegellátás számára $[2,3]$. Irodalmi összefoglalónk röviden bemutatja a landiolollal kapcsolatos jelenlegi ismereteket, a lehetséges indikációs köröket, illetve alkalmazásának módjait bizonyos kórképekben.

\section{A landiolol farmakológiai tulajdonságai}

A landiolol az intravénás beadását követően bolus telítő dózis esetén 2-4 perc alatt, infúziós (egyenletes) adagolás esetén 10-20 perc alatt fejti ki hatását. A molekuláris tulajdonságok (alacsony, kb. 0,5 kDa molekulatömeg, csekély fehérjekötődés) miatt nincs szignifikáns reabszorpció az OAT1, OAT3 vagy OCT2 renalis transzporterek révén megvalósuló aktív transzporttal. A fehérjekötés mértéke a plazmában elhanyagolható $(<10 \%)$ és dózisfüggő́. A landiololt elsősorban a plazma pszeudokolinészteráz és karboxilészteráz enzimei bontják le. A keletkezó fó metabolitok (M1 és M2) az anyavegyülethez képest elhanyagolható (1 : 200) Bl-blokkoló hatással bírnak, és a vesén keresztül eliminálódnak. A landiolol felezési ideje bolus esetén 3,2 perc, folyamatos infúzió esetén 4,5 perc $[2,3]$.

A landiolol közepes vagy súlyos fokú veseelégtelenség esetén is alkalmazható, hiszen a metabolitok hatása elhanyagolható, akkumuláció esetén sem számíthatunk elhúzódó hatásra [4]. Mivel azonban károsodott vesefunkció esetén nem állnak rendelkezésre a gyógyszerrel kapcso- latban nagy elemszámú klinikai vizsgálati adatok, az alkalmazási előirat körültekintő használatra hívja fel a figyelmet $[2,3]$.

Tekintettel arra, hogy májkárosodás esetén a plazma pszeudokolinészteráz-szintje, ezáltal a landiolol metabolizmusa is csökken, az alkalmazási elöirat alacsony kezdő dózist és körültekintő adagolást javasol ebben az esetben [3]. Takabata és mtsai vizsgálata alapján a májkárosodás során a landiolol plazmaszintje $40 \%$-kal nőtt, ugyanakkor a felezési idóben és az eliminációban nem találtak különbséget az egészséges önkéntesekből, illetve a májkárosodottakból álló két csoport között [5].

A landiolol nagy béta-1-receptor-selectivitassal (cardioselectivitassal ) bír ( $\beta 1$ : $\beta 2-255: 1$ ), gátolja a katecholaminok pozitív chronotrop hatásait a szívben, csökken a szívfrekvencia és az ectopiás pacemakersejtek spontán kisülése, lassul az ingerületvezetés, és megnyúlik a pitvarkamrai csomó refrakter időszaka. Mindezek mellett nincs hatása a $\mathrm{Na}^{+}$-és $\mathrm{Ca}^{2+}{ }^{2+}$ csatornákra a szívben, nem fejt ki membránstabilizáló aktivitást. A hatásmechanizmus alapján a landiolol minimális negatív inotrop, azonban erôs negatív chronotrop hatással rendelkezik. Alacsonyabb koncentráció mellett is effektíven csökkenti a szívfrekvenciát, mindemellett limitáltan csökkenti a vérnyomást [6]. Selectivitasából adódik továbbá, hogy bronchusszúkítő hatása gyakorlatilag elhanyagolható terápiás dózisban. A leggyakoribb mellékhatás - a többi béta-blokkolóhoz hasonlóan - a hypotensio és a bradycardia, ezek azonban ritkábban jelentkeznek (1-10\%), és a kezelés felfüggesztését követően hamar megszúnnek $[2,3]$.

A landiolol terápiásan indikált a kamrai frekvencia gyors csökkentésére tachycard kamrafrekvenciával járó pitvarfibrilláció és pitvari flutter esetén a perioperatív ellátásban, nem kompenzatorikus sinustachycardiában, illetve egyéb olyan esetben, amikor a kamrafrekvencia szabályozása gyorsan ható készítmény adását teszi szükségessé.

A terhesség relatív, a szoptatás abszolút kontraindikációja a landiolol alkalmazásának, ahogy a kritikus bradycardia, a másod- és harmadfokú pitvar-kamrai blokk, a hypotensio, a kardiogén sokk, az asztmás roham, a terápiarezisztens metabolikus acidózis és a kezeletlen pheochromocytoma is.

Európában és Magyarországon is engedélyezett adagolási séma szerint a terápiát $100 \mu \mathrm{g} / \mathrm{ttkg}$ bolusszal kell kezdeni, majd a fenntartó dózis $10-80 \mu \mathrm{g} / \mathrm{ttkg} /$ perc a szívfrekvencia függvényében. Potenciálisan hemodinamikai instabilitással járó esetekben (csökkent systolés bal kamrai funkció, szívelégtelenség, myocardialis infarctus, szívmútét, szepszis stb.) a gyógyszer bolus nélkül, kisebb dózisban (1-10 $\mu \mathrm{g} / \mathrm{ttkg} /$ perc) alkalmazható, és titrálandó $[2,3]$.

A landiolol hatásosságát és biztonságosságát a hemodinamikailag stabil állapotú, supraventricularis tachycardiában szenvedő betegek mellett számos más betegcsoport kezelésében is vizsgálták, amelyeknél a keringési 
instabilitás miatt egyéb béta-blokkolók alkalmazása kockázatosabb volna. Az alábbiakban ezeket a betegcsoportokat és tanulmányokat tárgyaljuk részletesen.

Landiolol adása esetén is kell számolni kombinatív gyógyszerkölcsönhatásokkal. Együttadása dihidropiridin-származékokkal fokozhatja a hypotonia kockázatát. Szívelégtelenségben szenvedő betegeknél más típusú béta-blokkolóval történő együttadása szívelégtelenséghez vezethet. Amennyiben a landiololt verapamillal, diltiazemmel, I. osztályba sorolt antiarrhythmiás szerekkel, amiodaronnal vagy digitáliszkészítményekkel adjuk, ingerületvezetési rendellenességekkel lehet számolni. Ajánlott ezen gyógyszerek mellett a landiolol dózisát szakszerű hemodinamikai monitorozás mellett gondosan beállítani. Ganglionblokkoló szerek, triciklikus antidepresszánsok, barbiturátok, fenotiazidok vagy antihipertenzívumok együttadása landiolollal fokozhatja, míg nemszteroid gyulladáscsökkentők és béta-blokkolók együttadása gyengítheti annak vérnyomáscsökkentő hatását. A katecholamin-depletáló szerek és szimpatolitikumok additív hatást fejtenek ki a landiolollal, így ezen gyógyszerekkel szimultán kezelt betegeknél is gondosan kell figyelni a landiolol dózisának beállítására. A landiolol metabolitjainak (M1 és M2) bármilyen mértékü gyógyszerkölcsönhatása jelenleg nem ismert $[2,3]$.

A továbbiakban tárgyalt tanulmányok mindegyikét ázsiai betegpopuláción végezték. Krumpl és mtsai ugyanakkor rámutattak, hogy a kaukázusi populációban a landiolol farmakokinetikai, farmakodinamikai tulajdonságai és biztonságossága megegyezik az ázsiaiakban tapasztaltakkal [7].

\section{Az intravénás béta-blokkolók jelentősége a klinikai gyakorlatban}

Az elmúlt több mint fél évszázadban a béta-blokkoló ágensek kifejlesztése, illetve későbbi klinikai alkalmazása a humán farmakoterápia egyik fó mérföldkőjeként tartható számon, hiszen a szintetikus gyógyszerek közül egyetlen más osztály sem bizonyított ilyen széles körü terápiás hasznosságot mind a szív- és érrendszeri, mind egyéb betegségek kezelése terén [8]. A különböző arrhythmiák előfordulásának gyakorisága az életkorral, illetve egyéb társbetegségek megjelenésével párhuzamosan növekszik. Az intenzív terápiás ellátás során megjelenő arrhythmiák és azoknak akár a hemodinamikát megingató hatása mind a morbiditást, mind a mortalitást növelhetik. Éppen ezen tények indokolják az antiarrhythmiás gyógyszerek fejlesztését, különös tekintettel az intenzív osztályos ellátás során frekvencia- és ritmuskontrollra használható intravénás, gyors hatású ágensekre [9].

Az 1. táblázatban foglaltuk össze a klinikai gyakorlatban jelenleg elérhető rövid és ultrarövid hatású intravénás béta-blokkolókat $[8,10,11]$.

Jelen ismereteink szerint - összehasonlítva a már korábban is klinikai használatban levő intravénás béta-blokkolókkal - a landiolol az egyetlen ultrarövid hatású, béta1-receptor-selectiv béta-blokkoló, mely limitált vérnyomáscsökkentő hatással bír effektív frekvenciakontroll mellett $[10,12]$.

\section{Landiolol alkalmazása a pitvarfibrilláció kamrafrekvencia-kontrolljára szívelégtelen betegek körében}

A magas kamrafrekvenciával járó pitvarfibrilláció jelentősen ronthatja a szívelégtelenségben szenvedő betegek klinikai állapotát és prognózisát, ezért a kamrafrekvencia kontrollja elsődleges fontosságú. Enyhe vagy mérsékelt tünetek esetén (NYHA I-III. funkcionális stádiumokban), amennyiben súlyos pangásos tünetek nem állnak fenn, elsőként az oralis béta-blokkoló a választandó kezelés (I. ajánlás A evidenciaszinttel), mely szükség esetén digoxinnal egészíthető ki (II/a ajánlás B evidenciaszinttel) [13]. Akut, súlyos tünetekkel járó szívelégtelenség esetén parenteralis digoxin vagy amiodaron jön szóba az aktuális nemzetközi irányelvek alapján (II/a ajánlás $\mathrm{C}$, illetve II/b ajánlás B evidenciaszinttel). Instabil keringésú beteg esetén mihamarabbi elektromos cardioversio a választandó eljárás [13]. A béta-blokkolók alkalmazhatóságát akut szívelégtelenségben negatív inotrop, vala-

1. táblázat | Intravénás béta-blokkolók tulajdonságainak összehasonlítása $[8,10,11]$

\begin{tabular}{|c|c|c|c|c|c|}
\hline Hatóanyag & A hatás beállásának ideje & Eliminációs féléletidő & A hatás hossza & Cardioselectivitas & Hatás \\
\hline Landiolol & 1 perc & 4 perc & 15 perc & $\beta 1 \gg>>\beta 2$ & $\begin{array}{l}\text { Vérnyomás } \\
\text { Szívfrekvencia } \downarrow \downarrow\end{array}$ \\
\hline Esmolol & 2 perc & 9 perc & $10-20$ perc & $\beta 1>>\beta 2$ & $\begin{array}{l}\text { Vérnyomás } \downarrow \\
\text { Szívfrekvencia } \downarrow\end{array}$ \\
\hline Atenolol & 2 perc & 6-7 óra & 12 óra & $\beta 1>\beta 2$ & $\begin{array}{l}\text { Vérnyomás } \\
\text { Szívfrekvencia } \downarrow\end{array}$ \\
\hline Metoprolol & 20 perc & 3-7 óra & 5- óra & $\beta 1>\beta 2$ & $\begin{array}{l}\text { Vérnyomás } \\
\text { Szívfrekvencia } \downarrow\end{array}$ \\
\hline Propanolol & $<10$ perc & 4 óra & 12 óra & $\beta 1=\beta 2$ & $\begin{array}{l}\text { Vérnyomás } \\
\text { Szívfrekvencia } \downarrow\end{array}$ \\
\hline
\end{tabular}


mint következményes perctérfogat- és vérnyomáscsökkentő hatásuk korlátozza. Tekintettel farmakodinamikai és farmakokinetikai (selectivitas és gyors elimináció) tulajdonságaira, a landiolol reális alternatívája lehet a digoxinnak és az amiodaronnak akut, súlyos tünetekkel járó szívelégtelenség esetén.

Nagai és mtsai a prospektív, multicentrikus, randomizált, egyszeres vak J-Land Study keretében hasonlították össze a landiolol és a digoxin hatékonyságát magas kamrafrekvenciájú ( $\geq 120 /$ perc) pitvarfibrillációban vagy pitvari flutterben szenvedő, NYHA III-IV. funkcionális stádiumú, csökkent systolés balkamra-funkciójú (LVEF 25-50\%), szívelégtelen betegek körében $(\mathrm{n}=200)$. A primer végpont a kezelés kezdetét követő második óra végére a 110/percnél alacsonyabb kamrafrekvencia elérése és a kamrafrekvencia 20\%-kal történő csökkenése volt. A vizsgálatban a landiolol dózisát $1 \mu \mathrm{g} / \mathrm{ttkg} /$ percról titrálták fel maximum $10 \mu \mathrm{g} / \mathrm{ttkg} /$ percig. A landiololcsoportban a betegek $48 \%$-a, a digoxincsoportban a betegek $13,9 \%$-a érte el a primer végpontot $(\mathrm{p}<0,0001)$. A két csoport között nem volt szignifikáns különbség sem az összes nemkívánatos esemény, sem külön a hypotensio előfordulásában. A landiolollal kezelt betegcsoportban három esetben vált szükségessé a kezelés felfüggesztése nemkívánatos esemény miatt (ischaemiás stroke, hypotensio és asthma bronchiale 1-1 esetben) $[14]$.

A fentebb részletezett J-Land Study rámutatott, hogy a landiolol effektívebb a digoxinnál magas frekvenciájú pitvarfibrillációban vagy pitvari flutterben szenvedő, NYHA III-IV. funkcionális stádiumú, csökkent systolés balkamra-funkciójú, szívelégtelen betegek körében. A tanulmány egyik korlátjának tartjuk, hogy egy csoportban vizsgálta a pitvarfibrillációt és a pitvari fluttert, miközben azok mechanizmusa különböző. Ez a különbözőség megjelenik a fentebb említett ritmuszavaroknak a landiololterápiára adott válaszában is az Oka és mtsai által 2019-ben közölt tanulmány szerint. A kutatócsoport azt találta, hogy a konszekutívan vizsgált 77, pitvari tachyarrhythmia (pitvarfibrilláció vs. pitvari flutter) kapcsán akutan dekompenzálódó szívelégtelen beteg esetében a landiololkezelés hatékonyabb frekvenciakontrollt biztosított alacsonyabb gyógyszerdózis mellett a pitvarfibrilláló betegek esetében [15].

Kobayashi és mtsai 2014-ben publikált tanulmányukban magas kamrafrekvenciájú pitvarfibrillációban $(\geq 120 /$ perc) és NYHA III-IV. funkcionális stádiumú akut dekompenzált szívelégtelenségben szenvedő betegek ( $\mathrm{n}=23$ ) körében vizsgálták az alacsony dózisú landiolol (1-2 $\mathrm{\mu g} /$ ttkg/perc) hatásosságát a kamrafrekvencia kontrolljára. Két órával a kezelés kezdete után a kamrafrekvencia szignifikánsan, átlagosan 22,4\%-kal csökkent. Az alacsony dózisú landiololkezelés mellett vérnyomáscsökkenés nem fordult elő a vizsgált betegcsoportban. Megfigyelésük szerint a kezelés első két órájában megtartott systolés balkamra-funkció mellett (LVEF $\geq 50 \%)$ szignifikánsan nagyobb mértékű kamra- frekvencia-csökkenés volt elérhető, mint a nem megtartott systolés balkamra-funkciójú $(\mathrm{LVEF}<50 \%)$ csoportban [16]. Hasonlót észleltek Ozaki és mtsai 33, magas kamrafrekvenciájú pitvarfibrillációban és NYHA III-IV. stádiumú szívelégtelenségben szenvedő beteg 8 órán keresztüli, alacsony dózisú landiololkezelését követően (kamrafrekvencia-csökkenés: HFpEF $38 \pm 12 \%$ vs. HFrEF $26 \pm 13 \%, \mathrm{p}<0,05)$ [17].

Wada és mtsai retrospektíven vizsgálták 39, magas kamrafrekvenciájú pitvari ritmuszavarban és szívelégtelenségben szenvedő betegben a landiololkezelés sikerességét befolyásoló tényezőket. Eredményeik szerint a betegek 74\%-ának csökkent a kamrafrekvenciája átlagosan $36,8 \%$-kal $(\mathrm{p}<0,0001)$. A jó válaszkészséggel bíró betegek kiindulási bal kamrai ejekciós frakciója szignifikánsan magasabb volt, mint a nem jó válaszkészséggel bíróké $(37 \pm 16 \%$ vs. $25 \pm 12 \%, \mathrm{p}=0,049)$. Nem volt különbség a két csoport között a kiindulási kamrafrekvenciát, a szívelégtelenség funkcionális stádiumát, a BNP-értéket és a balkamra-méreteket illetően sem. Összesen három esetben jelentkezett vérnyomásesés, ebből két esetben a systolés balkamra-funkció súlyosan csökkent volt [18].

Kobayashi és mtsai újabb, 2019-ben publikált, kis esetszámú tanulmányukban 9, akutan dekompenzálódó szívelégtelen (NYHA IV. stádiumú) és ezzel együtt magas kamrafrekvenciájú, pitvarfibrilláló beteg milrinonkezelését egészítették ki alacsony dózisú landiolollal (1,5-6,0 $\mu \mathrm{g} / \mathrm{ttkg} /$ perc), mely szignifikánsan javította a szívfunkciót és a különböző hemodinamikai paramétereket (szívfrekvencia, PCWP, szívindex, SVI, kevert vénás vér szaturációja) a vérnyomás változása nélkül [19].

\section{Landiolol alkalmazása myocardialis infarctus esetén}

Az Európai Kardiológus Társaság aktuális irányelvei alapján a béta-blokkolók korai alkalmazása stabil keringés mellett, kontraindikáció hiányában, STEMI-ben parenteralis formában megfontolandó (II/a A) [20], NSTE-ACS-ben pedig perzisztáló ischaemia esetén javasolt (IB) [21]. A béta-blokkolók jótékony hatása mögött a szív oxigénigényének és a malignus kamrai ritmuszavarok előfordulásának csökkentése állhat $[20,21]$.

Hanada és mtsai 96 fós, randomizált, kontrollált tanulmányukban vizsgálták kis dózisú (3 $\mu \mathrm{g} / \mathrm{ttkg} /$ perc), közvetlenül a percutan coronariaintervenció után indított landiolol rövid és hosszú távú hatásait, valamint biztonságosságát hemodinamikailag stabil állapotú STEMI-s betegek körében. Nem találtak különbséget az akut szakban a ritmuszavarok előfordulásában, illetve a 6 hónapos utánkövetés során a cardiovascularis események számában. A 6 hónapos kontroll során a landiololcsoportban a kontrollcsoporttal ellentétben a bal kamrai végdiastolés volumen indexe nem nőtt az akut szakhoz képest, ugyanakkor a bal kamrai ejekciós frakció javult. A landiolol mellett az akut szakban 10/perccel csökkent a szívfrekvencia, de nem találtak különbséget a landiolol 
és a placebo vérnyomásra kifejtett hatásában. A landiololcsoportban egy esetben észleltek bradycardiát, mely 10 perccel a gyógyszer felfüggesztését követően megszúnt [22].

Kiyokuni és munkacsoportja prospektív tanulmányukban vizsgálták 55, hemodinamikailag stabil állapotú, STEMI-ben szenvedő betegben a reperfúzió előtt elkezdett, alacsony dózisú ( $3 \mu \mathrm{g} / \mathrm{ttkg} /$ perc) landiololkezelés hatékonyságát és biztonságosságát. Landiolol mellett gyakrabban észleltek ST-szakasz-rezolúciót (64\% vs. $42 \%, \mathrm{p}=0,023$ ). Ritkább volt a „non-sustained” (nem tartós) kamrai tachycardia $(27 \%$ vs. $50 \%, \mathrm{p}=0,014)$ és a hypotensio ( $15 \%$ vs. $32 \%, \mathrm{p}=0,046)$ a felvételt követő 24. órában, valamint a Killip III. és IV. szívelégtelenség $(0 \%$ vs. $10 \%, \mathrm{p}=0,028)$ a kontrollcsoporthoz képest. Nem találtak különbséget a két csoport között a bradycardiát illetően [23].

\section{Landiolol alkalmazása elektromos vihar esetén}

Az elektromos vihart elszenvedő betegek ellátásában az első lépés a beteg stabilizálása mellett az esetleges precipitáló tényező felderítése és kezelése (ionzavar, ischaemia, szívelégtelenség, antiarrhythmiás gyógyszer kihagyása). Amennyiben ilyen tényező nem áll fenn, az elsőként választandó kezelés az intravénás béta-blokkoló és az amiodaron. Az esetek közel 30\%-ában nem megfelelő a terápiás válasz amiodaronra, ezért kompenzált keringés és nem súlyosan csökkent balkamra-funkció esetén választható antiarrhythmiás szer a prokainamid [24]. Második vonalbeli szer ezenfelül a mexiletin, valamint akut ischaemia esetén a lidokain. Gyakran alkalmazott kezelés az adrenerg válasz elnyomására a szedáció, szükség esetén a teljes anesztézia és a gépi lélegeztetés. Nem farmakológiás kezelésként alkalmazható még az „overdrive pacing”, a sürgős ablatio, továbbá szóba jöhet a ganglion stellatum blokádja is [25]. A béta-blokkolók alkalmazását a fennálló hemodinamikai instabilitás korlátozhatja, ilyen esetekben lehet hasznos a landiolol.

Miwa és mtsai prospektív tanulmányukban 42, III. csoportú antiarrhythmiás szerekre rezisztens, elektromos viharban szenvedő beteg körében vizsgálták a landiolol hatékonyságát. A betegek 60\%-a szenvedett ischaemiás szívbetegségben. A landiolol kezdő dózisa 2,5 $\mathrm{\mu g} / \mathrm{ttkg} /$ perc volt, melyet ineffektivitás esetén maximum $80 \mu \mathrm{g} / \mathrm{ttkg} /$ perc dózisig titráltak. A betegek 79\%-ában szúnt meg a kamrai ritmuszavar a kezelés alatt, a kórházi mortalitás elérte a 40\%-ot [26].

Wada és mtsai retrospektív tanulmányukban 12 , nem ischaemiás etiológiájú, III. csoportú antiarrhythmiás gyógyszerre rezisztens, kamrai tachycardiában szenvedó betegben vizsgálták a landiolol hatékonyságát előre jelző paramétereket. A 12 betegból 7-nél szûnt meg a kamrai tachycardia az alkalmazott terápia mellett (landiololdózis 1-10 $\mu \mathrm{g} / \mathrm{ttkg} /$ perc). Két esetben figyeltek meg vérnyomásesést, mely a kezelés felfüggesztéséhez vezetett.
A „responder” betegek beválasztáskor mért végsystolés $(44 \pm 11 \mathrm{~mm}$ vs. $64 \pm 13 \mathrm{~mm}, \mathrm{p}=0,02)$ és végdiastolés $(55 \pm 9 \mathrm{~mm}$ vs. $71 \pm 13 \mathrm{~mm}, \mathrm{p}=0,02)$ bal kamrai átmérője szignifikánsan alacsonyabb volt, mint a „nonrespondereké" [18].

A szerzők a potenciális vagy meglévő hemodinamikai instabilitás esetén megfontolandónak tartják a landiolol alkalmazását elektromos viharban.

\section{Landiolol alkalmazása súlyos szepsis vagy szeptikus sokkban jelentkező supraventricularis tachycardia esetén}

Az intenzív osztályon kezelt, kritikus állapotú betegek körében a pitvarfibrilláció gyakorisága 30\%, ebből 4,515\% új keletú szívritmuszavar, mely mind a rövid, mind a hosszú távú mortalitásra és morbiditásra kedvezőtlen hatással van. A szeptikus betegek 23-40\%-ánál jelentkezik pitvarfibrilláció [27].

Walkey és mtsai retrospektív tanulmányukban kimutatták, hogy a szeptikus betegek körében pitvarfibrilláció miatt intravénás kalciumcsatorna-blokkolókkal, bétablokkolókkal, digoxinnal és amiodaronnal végzett terápiák közül a béta-blokkolókkal érhető el a legjobb túlélés [28]. A béta-blokkolók - körültekintően megválasztva a betegeket és a lehető legalacsonyabb dózisban adagolva - biztonsággal alkalmazhatók noradrenalin mellett, szeptikus sokk esetén is. Mindazonáltal fontos, hogy az alkalmazott béta-blokkoló ne okozzon lényeges vérnyomáscsökkenést, és ne vezessen magasabb noradrenalinigényhez [29, 30].

Kakihana és mtsai prospektív, randomizált kontrollált J-LAND 3S tanulmányukban 151 beteg vizsgálatát követően azt találták, hogy a landiololcsoportban szignifikánsan több beteg érte el a szívfrekvencia normáltartományát (60-94/perc) az első 24 órában, illetve az új keletû arrhythmia megjelenése szignifikánsan alacsonyabb volt. Mindezek mellett a landiololkezelés jól tolerálhatónak bizonyult, ám alkalmazása szoros hemodinamikai monitorozás mellett javasolt a szepszises és szeptikus sokkos betegek körében a hypotensio magas rizikója miatt [31].

Az eddigi vizsgálatok alapján úgy túnik, hogy a landiolol biztonságosan alkalmazható szeptikus sokkban fellépő pitvarfibrilláció vagy pitvari tachycardia esetén, amennyiben a szívfrekvencia 120/perc felett van. A kezelés noradrenalin adása mellett is alkalmazható. További vizsgálatok szükségesek, hogy a landiololkezelésnek lehet-e hatása a mortalitásra szeptikus sokkban.

Okajima és mtsai retrospektív tanulmányukban 61, szeptikus állapotú, új keletû supraventricularis tachyarrhythmiák miatt vagy landiolollal (landiololcsoport, $\mathrm{n}=39$ beteg, dózis: $6,3 \pm 3,3 \mu \mathrm{g} / \mathrm{ttkg} /$ perc), vagy kalciumcsatorna-blokkolóval (dizopiramiddal/amiodaronnal) (kontrollcsoport, $\mathrm{n}=22$ ) kezelt beteget hasonlítottak össze. A landiololcsoportban a betegek kezdeti 
vérnyomása és szívindexe szignifikánsan alacsonyabb, kamrafrekvenciája szignifikánsan magasabb volt, mint a kontrollcsoportban. A landiololcsoportban már az első

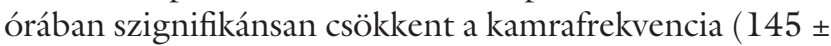
$14 /$ percről $119 \pm 28 /$ percre, $\mathrm{p}<0,01)$, míg a kontrollcsoportban ekkor még nem látszott különbség. A kezelés után 24 órával a landiololcsoportban szignifikánsan alacsonyabb kamrafrekvenciát sikerült elérni a kontrollcsoporthoz képest $(90 \pm 20 /$ perc vs. $109 \pm 18 /$ perc, $\mathrm{p}<0,05)$. A sinusritmus helyreállását illetően a landiololcsoportban az első órában 25,6\%, 24 órával később pedig $69,7 \%$ volt a conversio aránya, míg a kontrollcsoportban 24 óra után csupán 36,4\% $(\mathrm{p}<0.05)$. Landiolol mellett sem vérnyomásesés, sem bradycardia nem jelentkezett. Nyolc, landiolollal kezelt betegnél végeztek méréseket Swan-Ganz-katéterrel; a béta-blokkolóval történt kezelés ellenére a szívindex nem csökkent szignifikánsan [32].

Ezzel összhangban áll Ueda és mtsai vizsgálata, melynek keretében 29 szeptikus beteget kezeltek landiolollal. Az infúzió kezdete után 12 órával a pitvarfibrilláló betegek 73\%-a sinusritmusba konvertálódott, a kamrafrekvencia $125 \pm 22 /$ percről $92 \pm 12 /$ percre csökkent, ugyanakkor hemodinamikai instabilitás nem jelentkezett [33].

A hemodinamikai hatások mellett a szepszis állatkísérletes modelljeiben a landiololkezelés mellett alacsonyabb citokin, endotelin-1, tumornekrózisfaktor-alfa szinteket mutattak ki a szívben [34], a vesében [35] és a májban [36], valamint kisebb fokú vese- [35], máj- [36] és tüdőkárosodást [37] tapasztaltak, ami további előny lehet szeptikus állapotú betegek kezelése során.

\section{Landiolol alkalmazása a pitvarfibrilláció prevenciójára és kezelésére szívmütétet követően}

Szívműtéteket követően a pitvarfibrilláció gyakorisága 30-50\% lehet; ez magasabb mortalitással és fokozott stroke-kockázattal áll összefüggésben, emiatt fontos a ritmuszavar prevenciója és a fennálló ritmuszavar gyors rendezése [38].

Sezai és mtsai több prospektív, randomizált, placebokontrollált tanulmány keretében vizsgálták a landiolol hatékonyságát a pitvarfibrilláció prevenciójára szívmútéten átesett betegek körében [39, 40].

A PASCAL-tanulmányban 140, szív-tüdő motor segítségével végzett $\mathrm{CABG}$-mútéten átesett beteg körében vizsgálták az intraoperatíven elkezdett, 48 óráig tartó landiololkezelés előnyeit a placebóhoz képest. A landiololcsoportban a betegek $25 \%$-a, a kontrollcsoportban a betegek 35\%-a kapott a mütét elött béta-blokkolót $(\mathrm{p}=0,19)$. Nem volt szignifikáns különbség az ACEgátló/ARB, az aldoszteronantagonista, a sztatinterápia, illetve a cardiovascularis rizikófaktorok, a kiindulási hemodinamikai paraméterek és a gyulladásos, illetve ischaemiás biomarkerek vonatkozásában. A $2 \mu \mathrm{g} / \mathrm{ttkg} /$ perc landiololdózissal kezelt csoportban szignifikánsan ritkábban fordult elő pitvarfibrilláció, mint a kontrollcsoportban $(10 \%$ vs. $34,3 \%, \mathrm{p}=0,0006)$. Nem találtak különbséget a perioperatív mortalitásban és a vérnyomásértékekben, a landiololcsoportban azonban szignifikánsan alacsonyabb volt a troponin I és a CK-MB értéke, valamint a szívfrekvencia [39].

A randomizált PLATON-vizsgálat keretében 60, szívtüdő motor segítségével végzett szívmútéten átesett, csökkent systolés balkamra-funkciójú beteg körében vizsgálták a posztoperatívan elkezdett, minimum 48 óráig, maximum 5 napig alkalmazott, alacsony dózisú (2 $\mu \mathrm{g} / \mathrm{ttkg} /$ perc) landiolol hatását pitvarfibrilláció prevenciójára landiolollal nem kezelt csoporttal szemben. A vizsgálati protokoll alapján a landiolol leállítása előtt per os béta-blokkoló-kezelésre tértek át. Nem volt különbség a két csoport között a preoperatív béta-blokkoló-használatban (landiololcsoport 40\%, kontrollcsoport $53 \%, \mathrm{p}=0,3)$, ahogy az egyéb szekunder prevenciós gyógyszerek, rizikófaktorok, hemodinamikai paraméterek és a szívmütéttípus tekintetében sem. A landiololcsoportban $10 \%$, míg a kontrollcsoportban $40 \%$ volt a pitvarfibrilláció előfordulása $(p=0,002)$. Nem észleltek különbséget a két csoport között a vérnyomást illetően, míg a landiololcsoportban a teljes kezelés alatt alacsonyabb szívfrekvencia volt megfigyelhető. A landiololcsoportban az első posztoperatív napon szignifikánsan alacsonyabb troponin I-értéket, valamint az 1. posztoperatív naptól a 30. napig szignifikánsan alacsonyabb BNP-szintet mértek. A landiololágon szignifikánsan alacsonyabb volt a kórházi tartózkodási idő [40].

Tamura és mtsai 2017-ben publikált metaanalízisükben 6 prospektív, randomizált, placebokontrollált vizsgálatot - köztük a fent részletezett két tanulmányt - foglaltak össze. Az összesen 534 beteget elemző tanulmány eredményei szerint a landiolol effektíven előzi meg a pitvarfibrillációt szívmütéten átesett betegek között $(\mathrm{OR}=0,27, \mathrm{CI} \quad 0,18-0,42, \mathrm{p}<0,001)$, nem találtak azonban különbséget sem a kórházi mortalitást, sem a szövődményeket illetően a landiolol- és a kontrollcsoport között [4l].

Sakamoto és mtsai a prospektív, randomizált, multicentrikus JL-KNIGHT-vizsgálat keretében hasonlították össze a landiolol és a diltiazem effektivitását megtartott balkamra-funkciójú, nyitott szívmütéten átesett, posztoperatív pitvarfibrillációban szenvedő betegek körében. A tanulmány során a vizsgált 335 betegből 71-nél jelentkezett pitvarfibrilláció (21\%). A landiolol 8 órán belül hatásosabbnak bizonyult a sinusritmus helyreállításában $(54,3 \%$ vs. $30,6 \%, \mathrm{p}<0,05)$, ám 24 órán belül nem találtak különbséget a két gyógyszer hatásossága között. A kamrafrekvencia-csökkenés mindkét vizsgált szernél ugyanolyan mértékű volt. A landiololcsoportban szignifikánsan ritkábban jelentkezett vérnyomásesés (11,4\% vs. $30,6 \%, p<0,05)$, amit a negatív inotrop és a direkt vasodilatator hatás hiánya magyaráz. A diltiazemcsoportban 
4 esetben észleltek bradycardiát, míg a landiololcsoportban ez nem fordult elő [42].

Shibata és mtsai retrospektív tanulmányukban a landiololt és az amiodaront hasonlították össze nyitott szívmütéten átesett, posztoperatív pitvarfibrillációban szenvedő betegek körében. A landiololcsoportban $(\mathrm{n}=32)$ szignifikánsan gyorsabban állt helyre a sinusritmus, mint az amiodaroncsoportban $(\mathrm{n}=23)$ (medián idő: 75 perc $v s$. 150 perc, $\mathrm{p}=0,035)$, bár 24 óra alatt nem találtak különbséget a két gyógyszer hatásosságában. Az amiodaronnal kezelt csoportban 3 esetben észleltek bradycardiát, míg a landiololcsoportban egy alkalommal sem [43].

\section{Landiolol alkalmazása a pitvarfibrilláció prevenciójára és kezelésére nem szívsebészeti mütéteket követően}

A pitvarfibrilláció gyakorisága nyelőcső- és tüdőmútéteket követően 10-20\%, és ez a szívmütétekhez hasonlóan hosszabb kórházi tartózkodáshoz, magasabb morbiditáshoz és mortalitáshoz vezet, ezért mind a pitvarfibrilláció megelőzése, mind a fennálló szívritmuszavar kamrafrekvenciájának kontrollja és a sinusritmus helyreállítása nagy jelentőséggel bír [44].

Ojima és munkacsoportja prospektív, randomizált, placebokontrollált tanulmányukban 100, nyelőcsőműtéten átesett beteg körében vizsgálták a landiolol hatását a pitvarfibrilláció prevenciójára. Landiolol mellett ritkábban jelentkezett pitvarfibrilláció ( $10 \%$ vs. 30\%, p =0,012), és alacsonyabb volt a nyugalmi szívfrekvencia. Súlyos vérnyomásesést nem észleltek [45]. Hasonlóról számolt be Horikoshi is 40, nyelőcsőmütéten átesett beteget vizsgálva. Landiolol mellett 30\%-kal ritkábban jelentkezett pitvarfibrilláció a placebóhoz képest [46].

Mori és mtsai vizsgálatában 74 betegből 13-nál jelentkezett nyelőcsőmútétet követően tachyarrhythmia (17\%). Az esetek 77\%-ában bizonyult a landiololkezelés hatásosnak a frekvencia kontrolljára [47]. Niwa 231, nyelőcsőmütéten átesett beteg 10,4\%-ában észlelt posztoperatív tachyarrhythmiát. A 24 betegból 11 landiololt, 13 kalciumcsatorna-blokkolót és digitáliszt kapott. A landiolollal kezelt csoportban gyorsabban csökkent a kamrafrekvencia, és a sinusritmus is hamarabb állt helyre [48].

Yagi és mtsai prospektív, randomizált, placebokontrollált vizsgálatukban 43 , tüdőműtéten átesett betegben igazolták a landiolol hatékonyságát és biztonságosságát a pitvarfibrilláció megelőzésére $(5 \%$ vs. $28 \%, \mathrm{p}=0,03)$ [49]. Nakano munkacsoportjának 25, tüdőmütéten átesett, magas kamrafrekvenciájú pitvarfibrillációban szenvedő beteg $82 \%$-ánál sikerült megfelelő kamrafrekvenciakontrollt elérni, 56\%-uk sinusritmusba konvertálódott [50]. Nojiri 30, tüdőreszekción átesett és magas kamrafrekvenciájú pitvarfibrillációban szenvedő betegben a landiololt hatásosabbnak találta a kamrafrekvencia csökkentésében, mint a verapamil és a digoxin kombinációját, emellett a sinusritmus is hamarabb állt helyre a landiolol mellett, mint a kontrollcsoportban [51]. Az összes tanulmány biztonságosnak találta a landiolol alkalmazását, egyedül Niwa vizsgálatában észleltek egy betegnél nem jelentős vérnyomásesést és bradycardiát [48].

\section{Landiolol alkalmazása coronaria-CT- angiográfiás vizsgálat premedikációja során}

Coronaria-CT-angiográfiás vizsgálat előtt alapvető cél az alacsony szívfrekvencia elérése, egyrészt az optimális képminőségért, másrészt a beteg kontrasztanyag- és sugárterhelésének csökkentéséért, ezért magasabb frekvencia esetén a vizsgálat előtt általában béta-blokkolót alkalmaznak a radiológusok. A per os béta-blokkolók hatása azonban lassan alakul ki és lassan is szűnik meg, az utóbbi pedig megnyújtja a vizsgálat utáni megfigyeléshez, az esetleges súlyos bradycardia esetén monitorozáshoz szükséges időt [52]. Erre jelenthet megoldást az ultrarövid hatástartamú landiolol alkalmazása.

Osawa és mtsai 66, coronaria-CT-angiográfia előtt álló, per os metoprololterápia ellenére 60/perc feletti szívfrekvenciájú beteg körében vizsgálták $0,125 \mathrm{mg} /$ ttkg intravénás bolus landiolol effektivitását. Eredményeik szerint a frekvencia $(76 \pm 10 /$ percról $67 \pm 10 /$ percre, $\mathrm{p}<0,01)$ és a diastolés vérnyomás $(72 \pm 13$ Hgmm-ről $68 \pm 12$ Hgmm-re, p<0,01) is szignifikánsan csökkent a kezelés hatására, míg a systolés nyomás nem változott [53].

Hasonló eredményról számolt be Hirano munkacsoportja 39 beteget vizsgálva. A CT-vizsgálat előtt közvetlenül alkalmazott intravénás bolus landiolol $(0,125 \mathrm{mg} /$ ttkg) hatására a szívfrekvencia 77,1 $\pm 9,8 /$ percról $65,4 \pm$ $8,0 /$ percre csökkent $(\mathrm{p}<0,0001)$, ami lehetővé tette a betegek 65,4\%-ánál, hogy a coronaria-CT-angiográfiás vizsgálatra kevésbé optimális, 16 szeletes CT-vel is kielégítő minőségú képek készülhessenek [54]. Hirano egy másik, 258 fós, prospektív, randomizált, multicentrikus, placebokontrollált vizsgálatában is megerősítette, hogy a coronaria-CT-angiográfiás vizsgálat előtt közvetlenül alkalmazott, 0,125 mg/ttkg bolus landiolol a placebóhoz képest szignifikánsan csökkenti a szívfrekvenciát $(-19,1$ $\pm 8,1 / \min v s$. $-5,9 \pm 9,7 /$ perc, $\mathrm{p}<0,0001)$. A placebóhoz képest a landiololcsoportban szignifikánsan, de klinikailag nem jelentősen alacsonyabb vérnyomásértékeket mértek $(125,1 \pm 20,7 \mathrm{Hgmm}$ vs. 132,7 $\pm 20,7 \mathrm{Hgmm}$, $\mathrm{p}<0,05)$, de a nemkívánatos események $(\mathrm{p}=0,1299)$ és a súlyos vérnyomásesések $(\mathrm{p}=0,9911)$ számában nem volt különbség a két csoport között [55].

Koyoshi és mtsai 176 betegnél vizsgálták a landiololkezelés eredményességét coronaria-CT-angiográfiás vizsgálat előtt. A szívfrekvencia és a vérnyomás is szignifikáns mértékben csökkent a gyógyszer hatására. A magasabb alapfrekvenciájú betegek magasabb landiololdózissal ugyan, de szintén elérték a 65/perc célfrekvenciát (kezdeti 70-79/perc frekvenciánál 12,2 $\pm 5,3 \mathrm{mg}, 80-89$ / perc frekvenciánál $17,9 \pm 6,9 \mathrm{mg}, \geq 90 /$ perc frekvenciánál 20,9 \pm 7,6 mg volt az átlagos landiololdózis) [56]. 


\section{Következtetés}

A rövid hatástartamú, selectiv béta-1-receptor-blokkoló landiolol enyhe negatív inotrop hatása miatt elsősorban instabil vagy potenciálisan instabil keringésű betegek esetén alkalmazható a keringési instabilitás okától függetlenül kamrafrekvencia- vagy ritmuskontrollra.

A landiolol jelenleg kizárólag perioperatív pitvarfibrillációra és nem kompenzatorikus sinustachycardiára van törzskönyvezve. Mindemellett a gyógyszer hatékonyságát és biztonságosságát vizsgálták már súlyos akut szívelégtelenségben, szepszisben, valamint cardialis és nem cardialis mütétek posztoperatív szakában pitvari tachyarrhythmiák kezelésére, valamint eredményes lehet a III. csoportú antiarrhythmiás gyógyszerekre nem reagáló elektromos viharban. Az eddigi eredmények a landiolol pozitív hatását mutatják az ezen állapotok során fellépő tachyarrhythmiák kezelésében.

A J-Land Study alapján kijelenthető, hogy a landiolol a digoxinhoz képest gyorsabban csökkenti a kamrafrekvenciát súlyos, csökkent systolés balkamra-funkcióhoz társuló szívelégtelenségben és pitvarfibrillációban szenvedő betegek körében [14]. Több kisebb esetszámú vizsgálat igazolta, hogy megtartott systolés balkamrafunkció mellett a landiolollal még jelentősebb kamrafrekvencia-csökkenés érhető el, noha kemény klinikai végpontokat kitûző vizsgálatok nem állnak rendelkezésre $[17,18,57]$.

Szívmütétek perioperatív időszakában a landiolol a pitvarfibrilláció megelőzésére a PASCAL- [39] és a PLATON- [40], a kialakult pitvarfibrilláció hatékony kezelésére a JL-KNIGHT-tanulmány [42] alapján alkalmas.

Bár nem cardialis mútétek esetén nagy esetszámú, randomizált vizsgálatot nem végeztek sem a pitvarfibrilláció prevencióját, sem a kezelését illetően, a korábban részletezett tanulmányok alapján látható, hogy a kis dózisú landiolol hatékonyan csökkenti a posztoperatív pitvarfibrilláció előfordulását, és ritmuszavar esetén effektív kamrafrekvencia- és ritmuskontrollt biztosít negatív hemodinamikai válasz nélkül.

Ultrarövid hatástartamából következően a landiolol speciális indikációja lehet a coronaria-CT-angiográfia premedikációja. A gyógyszert a vizsgálat előtt 4-7 perccel alkalmazva megfelelő szívfrekvencia érhető el az optimális képminőség biztosítására. Az esetek nagy többségében a $0,125 \mathrm{mg} / \mathrm{ttkg}$ dózis elegendő, de szükség esetén nagyobb dózis alkalmazása is biztonságos lehet.

A korábbiakban ismertetett tanulmányoknak csak kis része nagy betegszámú, multicentrikus, prospektív, kettôs vak, randomizált vizsgálat. További vizsgálatok szükségesek a szívelégtelen betegek körében a landiolol és az amiodaron összehasonlítására, illetve elektromos viharban, hemodinamikai instabilitással járó akut coronaria szindrómában és szepszisben szenvedő betegek körében a gyógyszer hatásosságának igazolására. A szepszis állat- kísérletes modelljeiben a landiolol mellett észlelt alacsonyabb citokinszintek és csökkent célszervkárosodás szintén bizonyítást igényel humánvizsgálatok során.

Anyagi támogatás: A közlemény megírása anyagi támogatásban nem részesült.

Szerzôi munkamegosztás: R. P., K. B., Z. E.: Irodalomkutatás és a kézirat összeállítása. K. E., P. D., R. Z., S. É., F. Cs., G. L., M. B.: Részt vettek a kézirat szakmai véleményezésében. Z. E., K. B.: A kézirat véglegesítése. A cikk végleges változatát valamennyi szerző elolvasta és jóváhagyta.

Érdekeltségek: A szerzőknek nincsenek érdekeltségeik.

\section{Irodalom}

[1] Ono Pharmaceutical Co., Ltd. A short-acting selective $\beta 1$ block $\mathrm{er}, \mathrm{ONOACT}^{\circledR}$ for intravenous infusion $50 \mathrm{mg} / 150 \mathrm{mg}$ approved for additional indication of ventricular arrhythmia in Japan. Osaka, March 26, 2019. Available from: https://www. ono-pharma.com/sites/default/files/en/news/press/sm_ cn190326.pdf [accessed: July 3, 2021].

[2] Amomed Pharma GmbH. Rapibloc ${ }^{\circledR}$ (landiolol hydrochloride) summary of product characteristics - NL/H/3368/001-003/ DCBH/VDA/ALA/DNS. Vienna. Available from: https:// www.amomed.com/product/rapibloc-2/?lang=en [accessed: July 3, 2021].

[3] National Institute of Pharmacy and Nutrition. Landiolol - application instructions. [Landiolol - alkalmazási előirat.] Országos Gyógyszerészeti és Élelmezés-egészségügyi Intézet, Budapest. Available from: https://www.pharmindex-online.hu/ termekek/rapibloc-300-mg-por-oldatos-infuziohoz-60342 [Hungarian] [accessed: July 3, 2021].

[4] Shiga T, Ikeda T, Shimizu W, et al. Efficacy and safety of landiolol in patients with ventricular tachyarrhythmias with or without renal impairment - subanalysis of the J-Land II Study. Circ Rep. 2020; 2: 440-445.

[5] Takahata T, Yasui-Furukori N, Sakamoto J, et al. Influence of hepatic impairment on the pharmacokinetics and pharmacodynamics of landiolol hydrochloride, an ultra-short-acting betalblocker. Drugs R D 2005; 6: 385-394.

[6] Sugiyama A, Takahara A, Hashimoto K. Electrophysiologic, cardiohemodynamic and $\beta$-blocking actions of a new ultra-shortacting $\beta$-blocker, ONO-1101, assessed by the in vivo canine model in comparison with esmolol. J Cardiovasc Pharmacol. 1999; 34: 70-77.

[7] Krumpl G, Ulc I, Trebs M, et al. Pharmacokinetics and pharmacodynamics of two different landiolol formulations in a healthy Caucasian group. Eur J Pharm Sci. 2016; 92: 64-73.

[8] Frishman WH. Beta-adrenergic blockers: a 50-year historical perspective. Am J Ther. 2008; 15: 565-576.

[9] Zima E. Antiarrhythmic agents: evolution and usability in the cardiac intensive care. $[\mathrm{Az}$ antiaritmiás szerek evolúciója, használata a kardiológiai intenzív terápiában.] Cardiol Hung. 2017; 47: 71-81. [Hungarian]

[10] Krumpl G, Ulc I, Trebs M, et al. Bolus application of landiolol and esmolol: comparison of the pharmacokinetic and pharmacodynamic profiles in a healthy Caucasian group. Eur J Clin Pharmacol. 2017; 73: 417-428. 
[11] Health Products Regulatory Authority. Esmocard ${ }^{\circledR}$ - Summary of product characteristics, current version. Dublin, 06 October, 2020. Available from: http://www.hpra.ie/img/uploaded/ swedocuments/Licence_PA1353-001-001_06102020122300. pdf [accessed: July 3, 2021].

[12] Plosker GL. Landiolol: a review of its use in intraoperative and postoperative tachyarrhythmias. Drugs 2013; 73: 959-977. [Erratum: Drugs 2013; 73: 1255.]

[13] Ponikowski P, Voors AA, Anker SD, et al. 2016 ESC Guidelines for the diagnosis and treatment of acute and chronic heart failure: the Task Force for the diagnosis and treatment of acute and chronic heart failure of the European Society of Cardiology (ESC). Eur Heart J. 2016; 37: 2129-2200.

[14] Nagai R, Kinugawa K, Inoue H, et al. Urgent management of rapid heart rate in patients with atrial fibrillation/flutter and left ventricular dysfunction: comparison of the ultra-short-acting $\beta 1$ selective blocker landiolol with digoxin (J-Land Study). Circ J. 2013; 77: 908-916

[15] Oka E, Iwasaki YK, Maru E, et al. Differential effectiveness of landiolol between atrial fibrillation and atrial flutter/atrial tachycardia patients with left ventricular dysfunction. Circ J. 2019; 83: 793-800.

[16] Kobayashi S, Murakami W, Myoren T, et al. A low-dose $\beta_{1}$ blocker effectively and safely slows the heart rate in patients with acute decompensated heart failure and rapid atrial fibrillation. Cardiology 2014; 127: 105-113.

[17] Ozaki T, Yamada T, Morita T, et al. Urgent control of rapid atrial fibrillation using landiolol in patients with acute decompensated heart failure with reduced or preserved left ventricular ejection fraction. Eur Heart J. 2016; 37: 1319.

[18] Wada Y, Aiba T, Tsujita Y, et al. Practical applicability of landiolol, an ultra-short-acting $\beta 1$-selective blocker, for rapid atrial and ventricular tachyarrhythmias with left ventricular dysfunction. J Arrhythm. 2016; 32: 82-88.

[19] Kobayashi S, Myoren T, Kajii T, et al. Addition of a $\beta 1$-blocker to milrinone treatment improves cardiac function in patients with acute heart failure and rapid atrial fibrillation. Cardiology 2019 142: 195-202.

[20] Ibanez B, James S, Agewall S, et al. 2017 ESC Guidelines for the management of acute myocardial infarction in patients presenting with ST-segment elevation: the Task Force for the management of acute myocardial infarction in patients presenting with ST-segment elevation of the European Society of Cardiology (ESC). Eur Heart J. 2018; 39: 119-177.

[21] Roffi M, Patrono C, Collet JP, et al. 2015 ESC Guidelines for the management of acute coronary syndromes in patients presenting without persistent ST-segment elevation: Task Force for the management of acute coronary syndromes in patients presenting without persistent ST-segment elevation of the European Society of Cardiology (ESC). Eur Heart J. 2016; 37: 267-315.

[22] Hanada K, Higuma T, Nishizaki F, et al. Randomized study on the efficacy and safety of landiolol, an ultra-short-acting $\beta 1$ adrenergic blocker, in patients with acute myocardial infarction undergoing primary percutaneous coronary intervention. Circ J. 2012; 76: 439-445

[23] Kiyokuni M, Konishi M, Sakamaki K, et al. Beneficial effect of early infusion of landiolol, a very short-acting beta- 1 adrenergic receptor blocker, on reperfusion status in acute myocardial infarction. Int J Cardiol. 2016; 221: 321-326.

[24] Ortiz M, Martín A, Arribas F, et al. Randomized comparison of intravenous procainamide $v s$. intravenous amiodarone for the acute treatment of tolerated wide QRS tachycardia: the PROCAMIO study. Eur Heart J. 2017; 38: 1329-1335.

[25] Hendriks AA, Szili-Török T. Editor's choice - the treatment of electrical storm: an educational review. Eur Heart J Acute Cardiovasc Care 2018; 7: 478-483.

[26] Miwa Y, Ikeda T, Mera H, et al. Effects of landiolol, an ultrashort-acting betal-selective blocker, on electrical storm refrac- tory to class III antiarrhythmic drugs. Circ J. 2010; 74: 856863.

[27] Rehberg S, Joannidis M, Whitehouse T, et al. Landiolol for managing atrial fibrillation in intensive care. Eur Heart J Suppl. 2018; 20(Suppl A): A15-A18.

[28] Walkey AJ, Evans SR, Winter MR, et al. Practice patterns and outcomes of treatments for atrial fibrillation during sepsis: a propensity-matched cohort study. Chest 2016; 149: 74-83.

[29] Morelli A, Ertmer C, Westphal M, et al. Effect of heart rate control with esmolol on hemodynamic and clinical outcomes in patients with septic shock: a randomized clinical trial. JAMA 2013; 310: 1683-1691.

[30] Balik M, Rulisek J, Leden P, et al. Concomitant use of beta-1 adrenoreceptor blocker and norepinephrine in patients with septic shock. Wien Klin Wochenschr. 2012; 124: 552-556.

[31] Kakihana Y, Nishida O, Taniguchi T, et al. Efficacy and safety of landiolol, an ultra-short-acting $\beta 1$-selective antagonist, for treatment of sepsis-related tachyarrhythmia (J-Land 3S): a multicentre, open-label, randomised controlled trial. Lancet Respir Med. 2020; 8: 863-872.

[32] Okajima M, Takamura M, Taniguchi T. Landiolol, an ultrashort-acting $\beta 1$-blocker, is useful for managing supraventricular tachyarrhythmias in sepsis. World J Crit care Med. 2015; 4: 251257.

[33] Ueda TM, Yajima S, Misonoo Y. Landiolol therapy in septic patients: the feasibility study of the ultrashort acting betal adrenoreceptor blockade. Intensive Care Med. 2010; 36(Suppl 2): 86433.

[34] Seki Y, Jesmin S, Shimojo N, et al. Significant reversal of cardiac upregulated endothelin- 1 system in a rat model of sepsis by landiolol hydrochloride. Life Sci. 2014; 118: 357-363.

[35] Ogura Y, Jesmin S, Yamaguchi N, et al. Potential amelioration of upregulated renal HIF-lalpha-endothelin-1 system by landiolol hydrochloride in a rat model of endotoxemia. Life Sci. 2014; 118: 347-356.

[36] Yoshino Y, Jesmin S, Islam M, et al. Landiolol hydrochloride ameliorates liver injury in a rat sepsis model by down regulating hepatic TNF-A. J Vasc Med Surg. 2015; 3: 194.

[37] Matsuishi Y, Jesmin S, Kawano S, et al. Landiolol hydrochloride ameliorates acute lung injury in a rat model of early sepsis through the suppression of elevated levels of pulmonary endothelin-1. Life Sci. 2016; 166: 27-33.

[38] Fellahi JL, Heringlake M, Knotzer J, et al. Landiolol for managing atrial fibrillation in post-cardiac surgery. Eur Heart J Suppl. 2018; 20(Suppl A): A4-A9.

[39] Sezai A, Minami K, Nakai T, et al. Landiolol hydrochloride for prevention of atrial fibrillation after coronary artery bypass grafting: new evidence from the PASCAL trial. J Thorac Cardiovasc Surg. 2011 ; 141: 1478-1487.

[40] Sezai A, Osaka S, Yaoita H, et al. Safety and efficacy of landiolol hydrochloride for prevention of atrial fibrillation after cardiac surgery in patients with left ventricular dysfunction: prevention of atrial fibrillation after cardiac surgery with landiolol hydrochloride for left ventricular dysfunction (PLATON) trial. J Thorac Cardiovasc Surg. 2015; 150: 957-964.

[41] Tamura T, Yatabe T, Yokoyama M. Prevention of atrial fibrillation after cardiac surgery using low-dose landiolol: a systematic review and meta-analysis. J Clin Anesth. 2017; 42: 1-6.

[42] Sakamoto A, Kitakaze M, Takamoto S, et al. Landiolol, an ultrashort-acting $\beta_{1}$-blocker, more effectively terminates atrial fibrillation than diltiazem after open heart surgery: prospective, multicenter, randomized, open-label study (JL-KNIGHT study). Circ J. 2012; 76: 1097-1101

[43] Shibata SC, Uchiyama A, Ohta N, et al. Efficacy and safety of landiolol compared to amiodarone for the management of postoperative atrial fibrillation in intensive care patients. J Cardiothorac Vasc Anesth. 2016; 30: 418-422. 
[44] Balik M, Sander M, Trimmel H, et al. Landiolol for managing post-operative atrial fibrillation. Eur Heart J Suppl. 2018; 20(Suppl A): Al0-Al4.

[45] Ojima T, Nakamori M, Nakamura M, et al. Randomized clinical trial of landiolol hydrochloride for the prevention of atrial fibrillation and postoperative complications after oesophagectomy for cancer. Br J Surg. 2017; 104: 1003-1009.

[46] Horikoshi Y, Goyagi T, Kudo R, et al. The suppressive effects of landiolol administration on the occurrence of postoperative atrial fibrillation and tachycardia, and plasma IL-6 elevation in patients undergoing esophageal surgery: a randomized controlled clinical trial. J Clin Anesth. 2017; 38: 111-116.

[47] Mori K, Yamada K, Fukuda T, et al. Landiolol hydrochloride for early postoperative tachycardia after transthoracic esophagectomy. Surg Today $2014 ; 44: 848-854$.

[48] Niwa Y, Koike M, Iwata N, et al. Effect of landiolol hydrochloride on tachyarrhythmia after esophagectomy. Hepatogastroenterology 2014; 61: 1546-1551.

[49] Yagi K, Usuda J, Sakamoto A, et al. Perioperative landiolol infusion reduces the incidence of atrial fibrillation after pulmonary lobectomy: postoperative randomized controlled study. Open J Anesthesiol. 2016; 06: 119-123.

[50] Nakano T, Shimizu K, Kawashima O, et al. Effect of landiolol hydrochloride, an ultra-short-acting beta 1-selective blocker, on supraventricular tachycardia, atrial fibrillation and flutter after pulmonary resection. J Clin Pharm Ther. 2012; 37: 431-435.

[51] Nojiri T, Yamamoto K, Maeda H, et al. Efficacy of low-dose landiolol, an ultrashort-acting $\beta$-blocker, on postoperative atrial fibrillation in patients undergoing pulmonary resection for lung cancer. Gen Thorac Cardiovasc Surg. 2011; 59: 799-805.

[52] Bluemke DA, Achenbach S, Budoff M, et al. Noninvasive coronary artery imaging: magnetic resonance angiography and multidetector computed tomography angiography: a scientific statement from the American Heart Association Committee on cardiovascular imaging and intervention of the council on cardiovascular radiology and intervention, and the councils on clinical cardiology and cardiovascular disease in the young. Circulation 2008; 118: 586-606.

[53] Osawa K, Miyoshi T, Sato S, et al. Safety and efficacy of a bolus injection of landiolol hydrochloride as a premedication for multidetector-row computed tomography coronary angiography. Circ J. 2013; 77: 146-152.

[54] Hirano M, Yamashina A, Hara K, et al. A multicenter, open-label study of an intravenous short-acting $\beta 1$-adrenergic receptor antagonist landiolol hydrochloride for coronary computed tomography angiography by 16-slice multi-detector computed tomography in Japanese patients with suspected ischemic cardiac disease. Drugs R D 2014; 14: 185-194.

[55] Hirano M, Yamashina A, Hara K, et al. A randomized, doubleblind, placebo-controlled, phase III study of the short-acting $\beta 1$ adrenergic receptor blocker landiolol hydrochloride for coronary computed tomography angiography in Japanese patients with suspected ischemic cardiac disease. Clin Drug Investig. 2014; 34: 53-62.

[56] Koyoshi R, Shiga Y, Idemoto Y, et al. Safety of landiolol hydrochloride as a premedication for producing an appropriate heart rate for multidetector-row computed tomography coronary angiography. J Clin Med Res. 2018; 10: 22-26.

[57] Kobayashi S, Susa T, Ishiguchi H, et al. A low-dose $\beta 1$-blocker in combination with milrinone improves intracellular $\mathrm{Ca}^{2+}$ handling in failing cardiomyocytes by inhibition of milrinone-induced diastolic $\mathrm{Ca}^{2+}$ leakage from the sarcoplasmic reticulum. PLOS ONE 2015; 10: e0114314.

(Zima Endre dr.,

Budapest, Városmajor u. 68., 1122 e-mail: zima.endre@gmail.com)

\section{"Ordo est anima rerum." (Rend a lelke mindennek.)}

A cikk a Creative Commons Attribution 4.0 International License (https://creativecommons.org/licenses/by/4.0/) feltételei szerint publikált Open Access közlemény, melynek szellemében a cikk bármilyen médiumban szabadon felhasználható, megosztható és újraközölhető, feltéve, hogy az eredeti szerző és a közlés helye, illetve a CC License linkje és az esetlegesen végrehajtott módositások feltüntetésre kerülnek. (SID_1) 